José Antonio Seoane. Professor of Philosophy of Law at the Facultad de la Universidade da Coruña. His research interests focus on legal reasoning, theory of legal system, human rights, bioethics and bio-law. Author of "Hermeneutik und Typus. Historische und systematische Bemerkungen", in Juristische Hermeneutik zwischen Vergangenheit und Zukunft, Nomos Verlagsgesellschaft, Baden-Baden, 2013; "Si vis vitam para mortem. Argumentos sobre la planificación anticipada de la atención y la toma de decisiones en el final de la vida", in Triviño Caballero, Rosana \& Rodríguez-Arias, David (eds.), Cuestiones de vida y muerte. Perspectivas éticas y jurídicas en torno al nacer y el morir, Madrid, Plaza y Valdés, 2016; "Todo exceso es insano, también para el Derecho", in Elósegui María (coord.), Los principios y la interpretación judicial de los derechos fundamentales. Homenaje a Robert Alexy en su 70 aniversario, Zaragoza, Fundación Manuel Giménez Abad-Marcial Pons, 2016.

Contacto: jose.antonio.seoane@udc.es 


\section{IMPROVING BIOETHICAL \\ DECISION-MAKING WITH A \\ LITTLE HELP FROM LEGAL ARGUMENTATION}

DOI: $1017450 / 160107$

José Antonio Seoane

Universidade da Coruña

Reception date $10^{\text {th }}$ February 2015; acceptance date $8^{\text {th }}$ April 2016. This article is developed within a project research held at the Faculty of Law, Universidade da Coruña. This paper is a result of the research project "The discourse of Biorights. Philosophical and Legal Foundations, Features and Implementation" (reference number DER2014-52811-P), funded by the Spanish Ministry of Economy and Competitiveness.

\section{Abstract}

The most appropriate method for clinical decision-making is deliberation. The deliberative procedure aims to achieve wise and prudent decisions about health care taking into account facts, values and norms. Since deliberative reasoning is shared by healthcare professions, ethics and law, this paper introduces the structure and features of the bioethical deliberative procedure and suggests to improve it with some contributions from legal science and theories of argumentation.

\section{Keywords}

Bioethics, clinical decision-making, deliberation, legal argumentation 


\section{Resumen}

El método más adecuado para la toma de decisiones biomédicas es la deliberación. El procedimiento deliberativo pretende alcanzar decisiones prudentes y razonables tras tomar en consideración hechos, valores y normas. Al ser la racionalidad deliberativa un rasgo compartido por las profesiones asistenciales, la ética y el derecho, el presente artículo expone la estructura y las características del método bioético deliberativo y propone mejorarla mediante algunas contribuciones de la ciencia jurídica y las teorías de la argumentación.

\section{Palabras clave}

Argumentación jurídica, bioética, deliberación, toma de decisiones clínicas

Healthcare decision-making is guided by different methods, ${ }^{1}$ especially casuistry ${ }^{2}$ and principialism. ${ }^{3}$ The former stresses the ethical relevance of cases as guidelines and the latter develops a set of norms by means of specification, although it has been claimed that balancing in ethical deliberation is more effective and accurate approach to bioethical conflicts than those. ${ }^{4}$ Furthermore, from a broader political and ethical perspective deliberation and deliberative democracy have been considered the most promising theories to deal with bioethical problems. ${ }^{5}$

A wise and prudent decision is the purpose of the deliberative reasoning. Due to its ability to harmonize the different elements involved in healthcare decision-making (facts, values and norms) deliberation has been deemed the method of medical ethics ${ }^{6}$ leading to the development of a deliberative procedure ${ }^{7}$ that has been widely adopted by bioethics committees.

1. See J. Sugarman, D. P. Sulmasy, Methods in Clinical Ethics, Georgetown University Press, Washington D.C., 2010.

2. See A.R. Jonsen, M. Siegler, W. J. Winslade, Clinical Ethics. A Practical Approach to Ethical Decisions in Clinical Medicine, McGrawHill, New York, 2010.

3. See T. L. Beauchamp, J.F. Childress, Principles of Biomedical Ethics, Oxford University Press, New York, 2013.

4. See J. P. DeMarco, P. J. Ford, "Balancing in Ethical Deliberation: Superior to Specification and Casuistry", in Journal of Medicine and Philosophy, 31, 2006, pp. 483-497.

5. See A. Gutmann, D. Thompson, "Deliberating about Bioethics", in Hastings Center Report, 27, 1997, pp. 38-41.

6. See D. Gracia, "La deliberación moral: el método de la ética clínica”, in Medicina Clínica, 117, 2001, pp. 18-23.

7. See ibid.; D. Garcia, "Ethical Case Deliberation and Decision Making", in Medicine, Health Care and Philosophy, 6, 2003, pp. 227-233; D. Gracia, J. J. Rodríguez Sendín (dir.), Guías de Ética en la práctica médica 2. Ética en cuidados paliativos, Fundación de Ciencias de la Salud, Madrid, 2006; D. Gracia, “Teoría y práctica de la deliberación moral”, in L. Feito, D. Gracia, M. Sánchez (eds.), Bioética: el estado de la cuestión, Triacastela, Madrid, 2011, pp. 101-154. 
Since deliberative reasoning is shared by healthcare professions, ethics and law makes sense to complete deliberative procedure with some contributions of legal science and legal argumentation theories. Thus, this paper aims to theoretically explain how deliberation works in healthcare decision-making and how legal argumentation improves the deliberative procedure in its structure, foundations and implementation. Firstly, I describe the features and levels of a deliberative method for bioethics. Secondly, I characterise deliberative reasoning and explain its relation to bioethics. Thirdly, after this descriptive approach I develop a critical assessment of the method using some contributions of hermeneutics and theories of argumentation. Finally, I present a revised and updated version of the deliberative procedure for bioethical decision-making.

\section{The deliberative method}

\section{General features}

The deliberative method has brought a change in the language of bioethics, in that the original language of ethics was neither one of principles nor of rights, but rather one of values, one that is richer and more complex, flexible and even ecological. This leads us to consider that deliberation is not only a method for ethics or bioethics, but for practical reasoning in general, which is tantamount to say for human reasoning as a whole. ${ }^{8}$

The deliberative method rejects theoretical fundamentalism and pragmatism of decisionism. Its adoption as a procedure means abandoning the four bioethical principles theory, which is a simplification of the wealth and variety of moral reality. Decision-making is not a mechanical task that consists of establishing a hierarchy of principles and determining their order of priority in a given situation, and thus the deliberative method seeks to distance itself from an a priori rationality and creation of hierarchies that only do any exercise of prudence a futile one. ${ }^{9}$

8. See D. Gracia, “Prólogo a la segunda edición”, in D. Gracia, Procedimientos de decisión en ética clínica, Triacastela, Madrid, 2007, pp. 1-8; Id., "Teoría y práctica de la deliberación moral”, p. 120.

9. See ibid., pp. 6-7. 
The principles used in the initial version of the deliberative method ${ }^{10}$ have been replaced by values, ${ }^{11}$ accompanied by facts, duties and norms. ${ }^{12}$ The current version provides grounds for the method's meaning and characteristics, defines five steps in the argumentative process and includes a detailed theoretical reflection on deliberation presented in three orders: (1). Biological or anthropological: human being as animal deliberans; (2). Logical: deliberation as method for dialectical reasoning; and (3). Ethical or moral, which is about deliberation in three internally, related spheres: facts, values and duties. ${ }^{13}$

\section{Structure}

The deliberative procedure as a tool in biomedical decision-making is thus structured as follows ${ }^{14}$ :

I. Deliberation on facts.

1. Presentation of the case.

2. Deliberation of the case facts:

a. What is the situation? (Diagnosis).

b. How is it going to evolve? (Prognosis).

c. What can be done? (Treatment).

II. Deliberation on values.

3. Identification of the ethical problems presented by the case.

4. Choice of the moral problem to be discussed.

5. Determination of the values in conflict.

III. Deliberation on duties.

6. Identification of the extreme courses of action.

7. Search for intermediate courses of action.

8. Choose the optimal course of action.

IV. Test of the consistency of the decision.

9. Test of legality.

10. See D. Gracia, Procedimientos de decisión en ética clínica, Eudema, Madrid, 1991.

11. See D. Gracia, "Prólogo a la segunda edición”; in D. Gracia, Valor y precio, Triacastela, Madrid, 2013.

12. See D. Gracia, J. J. Rodríguez Sendín (dir.), Guías de Ética en la práctica médica 2. Ética en cuidados paliativos; D. Gracia,

J. J. Rodríguez Sendín (dir.), Guías de Ética en la práctica médica 6. Retos éticos en Atención Primaria, Fundación de Ciencias

de la Salud, Madrid, 2012.

13. See D. Gracia, “Teoría y práctica de la deliberación moral”, pp. 108-124.

14. See ibid., p. 125. 
10. Test of publicity.

11. Test of time.

V. Making the final decision.

\section{Deliberation and bioethics}

The deliberative procedure used by bioethics committees is characterised by a series of features that explain the reason for its existence, structure and functioning.

Biomedical decision-making has to be based on a method, since ethical issues cannot simply be ignored or dealt with intuitively, and neither clinical experience, the dictates of conscience, common sense or even imitation are in themselves sufficient. What is needed is a process for identifying, analysing and deliberating on the facts, values, rights and norms involved in healthcare practice, one that provides a rational justification for the decisions.

Deliberation is a method, i.e. a way, to reach a decision (metá, towards; hodós, road). The deliberative method provides a stable and systematic criterion for rational decision-making, free from the vagaries of chance and ad hoc choices. It is, however, purely instrumental in achieving a greater end, this being a prudent and wise decision that can provide a solution for a real case.

The deliberative procedure is more than just a method for biomedical decision-making; it is an instance of the conception of bioethics as civil ethics. ${ }^{15}$ Deliberation is the logic of daily life, ${ }^{16}$ a pedagogical tool for each person's life and for building our society ${ }^{17}$ that lies at the heart of ethics, politics and practical philosophy. ${ }^{18}$

Deliberation is the mode of knowledge that characterises practical reason, in which there is no room for apodictic or demonstrative knowledge, only probable knowledge. ${ }^{19}$ The method is deliberative since it is a form of practical reason in the rhetorical sense, as a deliberative genre ${ }^{20}$ that seeks to recommend the best alternative by combining

\footnotetext{
15. See D. Gracia, "Moral Deliberation: the Role of Methodologies in Clinical Ethics", in Medicine, Health Care and Philos$o p h y, 4$, 2001, p. 230; D. Gracia, "The foundations of medical ethics in the democratic evolution of modern society", in C. Viafor (ed.), Clinical Bioethics. A Search for Foundations, Springer, Dordrecht, 2005, pp. 33-40.

16. See D. Gracia, "La deliberación moral", in Boletín de la Academia Chilena de Medicina, 38, 2001, pp. 30-31.

17. See D. Gracia, “Teoría y práctica de la deliberación moral”, pp. 108-113.

18. See D. Gracia, “La deliberación moral”, pp. 30-32.

19. See Aristotle, Nicomachean Ethics, Hackett, Indianapolis, 1999.

20. See Aristotle, Art of Rhetoric, Harvard University Press, Cambridge (Mass.), 1926, 1358b, pp. 7-9.
} 
rhetoric and dialectics, ${ }^{21}$ and in the ethical sense as the practice of prudence and balancing conditions surrounding a decision, before acting. ${ }^{22}$

There are no a priori solutions, nor a science or techné of practical reasoning for clinical cases. ${ }^{23}$ The deliberative method is prudential: it pertains to the sphere of dialectics and requires prudence, understood as both an intellectual virtue and practical wisdom. ${ }^{24}$ Between the certainty of apodictic knowledge and mere opinion, prudent deliberation reconciles what is general with what is unique, seeking to establish the fair middle point. ${ }^{25}$ It is a creative process for knowledge ${ }^{26}$ that flexibly adjusts the general framework to fit the peculiarities of each new case, which always differs in one way or another from all previous cases. ${ }^{27}$

Although the final decision is made after a conflict of values has been identified, the deliberative method itself seeks to establish harmony rather than conflict. The conflict is only irresolvable when radical approaches are involved, whilst the aim of prudent and wise decisions is to apply both positive values to the greatest possible extent at the same time. Conflict lies in reality, not in the method. The healthcare professional (Level I) is experiencing a conflict that committee expresses using the language of values (Level II), before deliberating and dissolving this conflict of values and duties with the best possible solution (optimization: level III) for the initially conflicting values.

The deliberative method is problematic rather than dilemmatic. It does not simply identify two desirable options, since reducing deliberation to extreme courses of action is a falsification of reality, which is always more complex and displays a variety of intermediate possibilities. ${ }^{28}$ However, although extreme courses of action are not desirable, since they prevent the implementation of one positive value and the ethically optimal decision, identifying them does provide us with the ethical boundaries of the decision.

The problematic nature of this method separates it from dogmatism and the thesis of one right answer, both from a logical perspective, as a result of its connection with

\footnotetext{
21. See D. Gracia, "La deliberación moral”, p. 42.

22. See Aristotle, Nicomachean Ethics, 1140a25-b5; D. Gracia, "La deliberación moral”, pp. 29-45.

23. See Aristotle, Nicomachean Ethics, 1104a, pp. 3-8.

24. See Aristotle, Nicomachean Ethics, 1140a23-1140b34.

25. See P. Aubenque, La prudence chez Aristotes, Presses Universitaires de France, Paris, 1963, p. 64.

26. See D. Gracia, "La deliberación moral", p. 42.

27. See D. Gracia, "Deliberation and Consensus", in R. Chadwick, H. ten Have and E.M. Meslin (eds.), The SAGE Handbook of Health Care Ethics: Core and Emerging Issues, SAGE, Los Angeles/London/New Delhi/Singapore/Washington DC, 2011, p. 86.

28. See D. Gracia, “Deliberation and Consensus”, pp. 92-93.
} 
dialogue and dialectical reasoning, and from that of the anthropological unsuitability of the dilemma, which involves an erroneous simplification of reality. ${ }^{29}$

Deliberation is a complex activity that consists of a method of reasoning about facts, values and duties that takes abstract principles, specific circumstances and foreseeable consequences into consideration. It does not merely concern itself with reasons, but also with feelings, values, beliefs, traditions and expectations, all of which form part of our moral decision-making as human beings ${ }^{30}$ and does so by using axiological and ethical language, not commonly found in clinical practice.

We have not been trained for deliberation, which is a form of reasoning based on probability or plausibility requiring certain habits and qualities: intellectual humility, the ability to listen and prudence. ${ }^{31}$ The attitude and habit of the deliberation demand our respect for the other person as a valid interlocutor and distance us from fanaticism, ${ }^{32}$ confirming both the need for and value of other perspectives, which reveal varying approaches to reality. ${ }^{33}$

\section{A critical assessment of the deliberative method}

The deliberative method is unable to provide a solution to all the healthcare problems, and it does not attempt to do so. One of the main reasons for this are limitations imposed by the very design of the procedure itself, such as the requirement to analyse only one ethical problem at a time (Step 4), which means that analysis of a second or further ethical issue involves returning to Step 3, choosing a new problem and then deliberating on it independently (Step $4{ }_{2}$ ).

The method is also open to errors in the way it is used, such as the enforced search for extreme courses of action (Level III, Step 6) knowing full well that the subsequent choice will have to be made from amongst the intermediate alternatives (Step 7). Even worse is its spurious or hypocritical uses, which create a risk of substantive irrelevance, where any conclusion deriving from the method is acceptable, with no need for external control or justification; or that of moral comfort, when a decision is taken as being

29. See D. Gracia, "Moral Deliberation: the Role of Methodologies in Clinical Ethics”, p. 229.

30. See D. Gracia, "Philosophy: Ancient and Contemporary Approaches", in J. Sugarman, D. P. Sulmasy (eds.), Methods in Medical Ethics, p. 68.

31. See Aristotle, Nicomachean Ethics, 1003a-1004a; D. Gracia, “Deliberation and Consensus”, pp. 88, 93.

32. See D. Gracia, “Teoría y práctica de la deliberación moral”, pp. 124-129.

33. See D. Gracia, "Moral Deliberation: the Role of Methodologies in Clinical Ethics", p. 229; D. Gracia, "Prólogo a la segunda edición”, p. 8. 
"ethical" and "right" simply because it is an outcome of the method. These cases reveal even greater risks, such as that of accepting a rhetorical or pragmatic justification instead of looking for an authentic dialectical justification as a result of deliberation, or accepting a purely internal, procedural or intra-systemic justification that does not question the assumed concepts, values, duties and norms.

Taking the latest version of the deliberative procedure ${ }^{34}$ as our point of reference, I shall now assess the significance of each level and step, introducing suggestions that strengthen its justification and implementation.

\section{Facts}

Two steps or two levels? Facts are the starting point of deliberative procedure. It is important to distinguish between two steps within this level (Level I), namely the presentation of the case (Step 1), which does not involve any deliberation, and the beginning of deliberation proper, in which facts of the case are clarified and defined (Step 2).

The impure nature of the facts: facts and values. Differentiating between the factual level (Level I) and the axiological and normative levels (Levels II, III, IV and V) helps us to organize the deliberative procedure and the decision-making process. This distinction is an analytical or operational one, but does not express the positivistic separation between facts and values, since all facts are value-laden. ${ }^{35}$

It is impossible to avoid the normative influence when characterising facts, which are conditioned by the values, duties and norms of the case. They are not a mere description but rather a selection of ethically relevant features, and in this sense cannot be established in advance, but are instead shaped by deliberation. Thus, method acquires a certain hermeneutical tone. ${ }^{36}$

Facts first. For the proper function of deliberative procedure, it is necessary to clarify matters of fact that have been resolved unsatisfactorily, either as the result of a lack of certain empirical knowledge at the time of determination and deliberation on facts (Level I), or of confusing empirical matters with axiological or normative ones when identifying the ethical problems (Level II, Step 3), or even of having paid insufficient attention to certain facts that subsequently acquire greater relevance in accordance with the ethical issue that has been chosen (Level II, Step 4).

34. See D. Gracia, “Teoría y práctica de la deliberación moral”, pp. 101-154.

35. See D. Gracia, "Philosophy: Ancient and Contemporary Approaches”, pp. 55-71; D. Gracia, Valor y precio.

36. See D. Gracia, “Teoría y práctica de la deliberación moral”, p. 121. 
After Level 1, uncontroversial facts cease to be the subject of deliberation and become premises in the axiological and normative deliberation (Levels II and III, respectively). ${ }^{37}$ However, if a matter of fact has been unsatisfactorily resolved or new matters of fact arise in the subsequent levels, we will have to return to the level of facts (Level I). The discursive theories of legal argumentation have resolved this issue in the form of transition rules, ${ }^{38}$ whilst hermeneutics contemplate such a possibility ab initio as a way of determining the facts by means of a permanent dialogue between factual and normative elements. ${ }^{39}$

\section{Values}

\section{Identifying ethical issues}

Confusing facts with values. The axiological level poses the problem of managing the language of values. Moreover, the identification of ethical issues combines the language of values with duties, creating further difficulties. It is important not to confuse technical or clinical issues (Step 2), which pertain to the factual dimension (Level I) -e.g. whether an intervention is clinically indicated-, with ethical issues (Step 3), which pertain to the axiological dimension (Level II) -e.g. questioning the rightness or ethical significance of a patient's refusal of a clinically indicated intervention.

\section{Choosing a new ethical problem}

If, once the final decision has been made (Level V), a further ethical problem still needs to be resolved (Step 3), we will have to start the deliberation process from the beginning again by choosing a new ethical problem (Step 4) and repeating all the subsequent steps.

There may be times when, depending on the relation between the first problem to be chosen and those chosen subsequently, deliberation in the latter case may lack the ethical purity of that in the former, since it is hard to ignore argumentations and conclusions pertaining to the previous issue.

\footnotetext{
37. See C. Perelman, L. Olbrechts-Tyteca, The New Rethoric. A Treatise on Argumentation, University of Notre Dame Press, Notre Dame, 1969, pp. 68-69.

38. See R. Alexy, A Theory of Legal Argumentation. The Theory of Rational Discourse as Theory of Legal Justification, Oxford University Press, Oxford, 1989, p. 206.

39. See A. Kaufmann, Rechtsphilosophie, Beck, München, 1997.
} 


\section{Identifying values in conflict}

Confusing values and duties. Language of values is not an easy one to use. ${ }^{40}$ Benefit should not be described as a value, since it is really the outcome of an action taken to fulfil a duty (Level III). Furthermore, both of the conflicting values are potentially beneficent for the patient, and it is precisely the uncertainty as to what is truly beneficent in the case in question that gives rise to ethical conflict experienced by the healthcare professional (Step 5).

Values, principles and duties. In line with the above, and eluding the vague and abstract language of principles, neither beneficence nor non-maleficence should be considered as values (Level II), since they are really actions (do good, refrain from doing harm) performed in order to fulfil the duty to implement the corresponding positive value (Level III).

\section{Duties}

The ideal dimension and the real dimension. One of the functions of the tests of consistency is to conclude the deliberative procedure with a decision that can be applied hic et nunc and provides an answer to the professional's query. This connection with the real world by no means rules out the possibility of ideal solutions with no immediate practical consequences; indeed, the tests of consistency facilitate and justify the coexistence of both dimensions. Nevertheless, we should not identify the ideal dimension with deliberation on values (Level II), nor identify the real dimension with deliberation on duties (Level III) ${ }^{41}$ because the normative level of duties allows for the simultaneous presence of both dimensions: real and ideal.

Optimal and sub-optimal courses of action. For this reason and in accordance with the nature of the deliberative procedure, if the optimal course of action (Step 8, Level III) fails to pass any of the tests of consistency (Level IV) we will need to return to Step 8 in order to choose a new course of action from the intermediate ones remaining (Step 7), this being the second-best ethical option or a sub-optimal course of action (Step $8_{2}$ ).

\section{Tests of consistency}

The justification for testing consistency. Tests of consistency are ways of externally justifying the deliberative method, thereby reinforcing the normativity of the decision that

40. See D. Gracia, Valor y precio, pp. 223-245.

41. See D. Gracia, "Deliberation and Consensus", p. 89. 
has been made from an ethical, legal and practical standpoint. Refining this justification and normativity and adding two further tests of consistency will make them even more robust.

\section{Test of legality}

Is this a legal decision? ${ }^{22}$ Once the case has been analysed from a purely ethical standpoint and the deliberative procedure has concluded, we also need to see whether the decision " $[. .$.$] is also viable from a legal standpoint, because it cannot be generally con-$ sidered prudent to make decisions in breach of law." ${ }^{43}$

Justification of the test of legality and its position at the end of the procedure. The test of legality is justified insofar as the law is deemed to be the normative system that establishes the common criteria for harmonious coexistence in a given society, and one that claims to be universal, comprehensive and supreme.

The reason for introducing this test at the end of the procedure is to prevent it from supplanting the ethical reflection and to ensure the purity of the ethical deliberation, without identifying legal norms as authoritative arguments or making any juris et de jure presumptions of correctness -since it is enshrined in law it is righ-thus avoiding to use the law as a substitute for the moral answer.

What is legal is not necessarily ethically right, thus, it makes good sense to include the legal dimension at the end of the procedure. This also reinforces the distinction between ideal discourse, which determines the normative horizon or the ethically optimal answer in the ideal community of communication ${ }^{44}$ or ideal deliberative community, ${ }^{45}$ and real discourse, which fits the actual conditions of the case.

The meaning and scope of the term "legality". Legality should be understood in its broadest sense, including both legislation and case law. Legality is equivalent to current applicable legislation, and thus excludes laws that have been repealed or have not yet come into force, as well as legislation that cannot be applied to material or territorial reasons. However, in order to enrich the deliberative procedure and the grounds for the final decision, it is possible to use legislative examples that are not applicable to the case to show courses of action considered to be ethically recommendable in other circumstances (e.g. legislation in other countries that provides a service or authorises

42. See D. Gracia, "La deliberación moral: el método de la ética clínica”, p. 27.

43. D. Gracia, “Teoría y práctica de la deliberación moral”, p. 149.

44. See J. Habermas, "Wahrheitstheorien”, in J. Habermas, Vorstudien und Ergänzungen zur Theorie des kommunikativen Handelns, Suhrkamp, Frankfurt am Main, 1984, pp. 175-183.

45. See D. Gracia, "Deliberation and Consensus", p. 87. 
an intervention that are not recognised in the territory where the query has been made). For its part, case law is also of normative value, normally in the form of a precedent that guides the interpretation of the law or resolves legally relevant situations with no legal answer, and should therefore be contextualised in time and linked to the legislation applying at the time of the decision in order to avoid any anachronism.

Finally, legal norms should be seen and interpreted systematically, relating the immediately applicable norm to the whole set of related legal provisions.

Divergence between the ethical and legal answers. What should we do when a decision fails the test of legality, or in other words, when the ethically optimal course of action is illegal? Legality is not the same as legitimacy. As the deliberative method is a process of ethical assessment, the reasonable and coherent answer would be to say at Level $\mathrm{V}$ that there is an ethically optimal decision (Step 8: Level III), which is not a legal one at the time the decision is made (because it fails to meet the requirements of Step 9: Level IV).

Since the method is intended to be practical and to provide a solution to healthcare professionals' conflicts, we should return to the intermediate courses of action (Step 7: Level III) and find a new suboptimal course of action that we then carry forward to Step 8 (Step $8_{2}$ or Step $8_{L}$ ) and subject the decision to the scrutiny of the tests of consistency (Level IV), in particular the test of legality (Step 9), until we have determined a course of action that is both ethically right and legal. This will enable the professional to implement the committee's proposal, and the latter to fulfil its advisory function.

Although the final decision will always be up to the professional who has made the query, it would be unreasonable, just to invite him or her break the law by suggesting a course of action that requires him or her to disobey a legal norm. On the other hand, if we include two answers at Level V -the ethically optimal, but illegal course of action (Step $8_{1}$ or Step $8_{\mathrm{L}}$ ) and the ethical suboptimal, but legal one (Step $8_{2}$ or Step $8_{\mathrm{L}}$ ), this will provide the professional with full and accurate information on the committee's deliberation and more elements for analysis.

Furthermore, a dual answer of this kind fulfils an additional function by bringing to light a situation that may indicate the need for legal reform, thus extending the beneficial effects of the committee's work. If the existence of a legal norm does not in itself imply its fairness or material correctness, the committee's deliberation would provide arguments to justify a refusal to abide by law or suggest legal reform. 


\section{Test of publicity}

Would you be able to publicly defend your decision, and would you have sufficient arguments to do so? ${ }^{46}$

Justification and formulation of the test of publicity. An appropriate formulation of the test of publicity could be the Kantian transcendental formula of public law: "All actions relating to the rights of other men are unjust, if their maxim is not consistent with publicity." ${ }^{37}$ Kant considers this not merely as an ethical principle, but also as a legal one. Ethics discourse has subsequently understood it as a ground rule for practical argumentation related to the requirement for openness and sincerity: all rules or arguments must be capable of being shown universally and openly. ${ }^{48}$

The rhetorical nature and the limits of the test of publicity. Test of publicity refers to the possibility of knowing arguments on which the decision is based, but it is in no way designed to guarantee the decision's correctness or fairness. The prevailing element is the decision's acceptability, and in this sense it reflects a rhetorical, rather than an argumentative or dialectical, rationality. It would be possible deliberate with the sole intention of persuading or gaining assent of the audience, adapting one's arguments to ensure its adherence..$^{49}$ Publicity is first and foremost aimed at the widespread knowledge and efficacy of the decision that has been reached through the deliberative process, and can be measured by how much the healthcare professional agrees or is satisfied with it. ${ }^{50} \mathrm{It}$ is no guarantee, however, of the rightness of the decision that has been reached, unless what is morally right is identified with persuasion, efficacy or majority.

Furthermore, nor is publicity a guarantee of universalization, since it is sufficient to obtain the agreement, or absence of disagreement, of the majority of the audience. The test of publicity ratifies its dimension of efficacy by operating with a utilitarian criterion: the greatest good for the greatest number.

Knowledge and understanding: intelligibility. Publicity is a guarantee of knowledge of access to decision and arguments on which it is based, but not of it being able to be understood. The use of highly technical or specialized arguments would be enough to ensure that the addressees would be unable to understand them. To the test of publicity,

\footnotetext{
46. See D. Gracia, “La deliberación moral: el método de la ética clínica”, p. 27; D. Gracia, “Teoría y práctica de la deliberación moral", p. 150.

47. I. Kant, Zum ewigen Frieden (1795), in I. Kant, Gesammelte Schriften, VIII, Königlich Preussischen Akademie der Wissenschaften, Walter de Gruyter, Berlín, 1928, p. 381.

48. See R. Alexy, A Theory of Legal Argumentation, pp. 130-131.

49. See C. Perelman, L. Olbrechts-Tyteca, The New Rethoric, pp. 4, 14, 23-25.

50. See ibid., p. 45.
} 
we should therefore add the requirement of intelligibility, intended as a guarantee of understanding and a ratification of respect for the addressee and his or her status as a valid interlocutor. Intelligibility does not so much refer to the way in which arguments and its subsequent decision are presented as to their being understood, and not only guarantees their ethical justification, but also their accessibility. Put another way, publicity is not just transparency: it is also accessibility and intelligibility.

All the arguments: sincerity and saturation. The test of publicity should be seen as a test of sincerity, honesty or truthfulness. Sincerity refers to the speaker's coherence, but is in itself insufficient, since it does not require one to say everything one knows, only that what is being said is believed by the speaker: every speaker may only assert what he or she actually believes. ${ }^{51}$ Honesty, on the other hand, requires those participating in the deliberative procedure not referring to justification they know is not valid, ${ }^{52}$ but is no guarantee that all the arguments are made known, since it does not require all the reasons, or everything the speaker believes, to be made public.

It is therefore not enough for arguments to be made public: the requirement is for all the arguments on which the decision is based to be made public. One way of ensuring this is to introduce the requirement of truthfulness, which reinforces confidence in the deliberative process by combining two characteristics or virtues: accuracy and sincerity. ${ }^{53}$ An alternative way is to fulfil the requirement of saturation, ${ }^{54}$ according to which an argument (optimal course of action: Step 8) is only complete and justified if it contains all its premises. Saturated premises or arguments can be both empirical (Level I) and normative, referring to values and duties (Levels II and III), and are always open to being discussed or questioned anew.

\section{Test of time}

Would you take the same decision in a few more hours or days?55 "It is a question of knowing whether the decision has been made as the result of a rush of emotion."56

Verification and the rebus sic stantibus clause. The purpose of the test of time is not so much to ratify the decision after a certain amount of time has passed, as to subsequently verify that deliberative procedure and decision are not insufficiently justified, due to

51. See R. Alexy, A Theory of Legal Argumentation, p. 188.

52. See A. Aarnio, The Rational as Reasonable. A Treatise on Legal Justification, Reidel, Dordrecht, 1987, p. 197.

53. See B. Williams, Truth \& Truthfulness. An Essay in Genealogy, Princeton University Press, Princeton, 2002, p. 11.

54. See R. Alexy, A Theory of Legal Argumentation, p. 245.

55. See D. Gracia, "La deliberación moral: el método de la ética clínica”, p. 27.

56. D. Gracia, “Teoría y práctica de la deliberación moral”, p. 150. 
an incomplete analysis of the facts, values and norms as a result of the circumstances (emotional, severe restrictive or emergency circumstances).

According to the rebus sic stantibus clause, whilst the circumstances remain the decision taken as a result of the deliberative procedure will continue to be the final decision.

The principle of inertia and justification of any change. The test of time is no obstacle to a decision possessing certain characteristics proper to the specific circumstances in which it was adopted, nor the persistence over time of the criterion that has been followed, thereby acting as a guarantee of certainty. One reason to justify its inclusion and explain its significance would be the principle of inertia, basis of the stability of spiritual and social life. Until proven otherwise, we must suppose that the stance adopted will continue forward into the future. Thus, once accepted a decision can neither be rejected nor abandoned without sufficient motive. ${ }^{57}$ Only change requires justification, ${ }^{58}$ and those who claim a decision to be erroneous, should provide further reasons for abandoning it and propose a new answer.

Furthermore, from the normative standpoint, test of time relates to the doctrine of precedent and the principle of justice. ${ }^{59}$

\section{A new test of consistency: test of universalizability}

Justification and formulation of the test of universalizability. Equality of treatment, the foundation stone of formal justice, is utmost important in ethics and law. The test of publicity is unable to provide a guarantee of this requirement; this can be done, however by means of a new test, that of universalizability. This test furnishes us with a discursive or argumentative justification, as opposed to the rhetorical nature of test of publicity, which offers insufficient guarantees in societies that admit an unfair or discriminatory treatment of their members that could be defended in public but which would fail the test of universalizability. This new test of consistency gives us something different and more demanding than publicity, which only requires a decision to be known (and accepted) by the majority, whilst the test of universalizability refers to the universe of addressees and also to justice and equality of treatment.

Kant provides us with a formulation of this test in the first expression of his categorical imperative: "Act only in accordance with that maxim whereby you can at

57. See C. Perelman, L. Olbrechts-Tyteca, The New Rethoric, p. 106.

58. See R. Alexy, A Theory of Legal Argumentation, pp. 195-197.

59. See C. Perelman, L. Olbrechts-Tyteca, The New Rethoric, pp. 218-219; R. Alexy, A Theory of Legal Argumentation, pp. 274-279. 
the same time will that it become a universal law." ${ }^{60}$ Furthermore, "I ought never to conduct myself otherwise than so that I could also will that my maxim become a universal law."61

The meaning of this test can be explained by the rule of generalization, common in analytical theories of legal argumentation, which states that one may not refer to a value judgement that one would not generalize to cover other similar cases; or a willingness for role exchange, according to which one should be able to accept the consequences of decisions affecting others where one was in the position of those persons. ${ }^{62}$

Universalizability, dignity and rights. Although the deliberative method and practical decision-making require an individual analysis of each case, all of them nevertheless share a common starting point, namely the inadmissibility of unjustified discrimination. Furthermore, their connection with precedent or requirements of equality invokes an external ethical justification, complemented by Kant's second formulation of his categorical imperative: "Act so that you treat humanity, whether in your own person as in that of any other, always at the same time as an end and never merely as means", ${ }^{63}$ as well as by the third: "In the realm of ends everything has either a price or a dignity. What has a price can be replaced by something else which is equivalent; on the other hand, what is above all price, and therefore admits no equivalent, has a dignity" ${ }^{64}$ or even the invocation of material ethical and legal universals such as human rights. ${ }^{65}$

\section{A new test of consistency: test of feasibility}

Justification and meaning of the test of feasibility. Deliberative method aims to provide an answer to a clinical question by formulating a course of action that can be implemented. It must be possible to implement or apply the course of action stated in the final decision (Level V): if not, method's practical purpose would be thwarted. We therefore have to introduce an additional test of consistency: feasibility. ${ }^{66}$

This test presupposes an empirical knowledge of the facts and their context, confirming the relevance of the factual dimension (Level I). It may not be possible, however, to implement the ethically optimal course of action (Step 8) due to a lack of per-

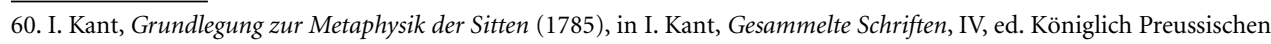
Akademie der Wissenschaften, Walter de Gruyter, Berlín, 1911, pp. 421, 6-7.

61. Ibid., pp. 8-9.

62. See R. Alexy, A Theory of Legal Argumentation, p. 203; A. Aarnio, The Rational as Reasonable, p. 198.

63. I. Kant, Grundlegung zur Metaphysik der Sitten, pp. 429, 10-13.

64. Ibid., pp. 434, 31-34.

65. See J. A. Seoane, “La relación clínica del siglo XXI: cuestiones médicas, éticas y jurídicas”, en Derecho y Salud, 16, 2008, pp. 1-28.

66. See R. Alexy, A Theory of Legal Argumentation, p. 205. 
sonal, technical, financial or other resources. In this event, it will be necessary to offer a second-best option that can be implemented, in keeping with the method's practical intentions and in order to provide a satisfactory answer to the healthcare professional's query (by returning to Step 7 and choosing one or more new intermediate courses of action before proceeding once again to Step 8), since the case in question could be solved by adopting a sub-optimal course of action (Step $8_{2}$ or Step $8_{\mathrm{F}}$ ).

An optimal decision that could not be implemented would be admissible as a theoretical exercise if a committee were using the method to draft a general recommendation, but not in the case of a specific consultation. The possibility of theoretical learning is parasitical to the latter: it goes against the purpose of deliberative method to conclude the procedure by proposing an ethically wise course of action (Step 8) of no practical consequence because it fails to provide a solution to the real problem (Step 8 should lead to Level $\mathrm{V}$, that of the final decision, after passing a test of feasibility in Level IV). It must therefore be possible to ensure practical feasibility of the decision that concludes deliberate process. Non-feasible courses of action are admissible when identifying intermediate courses of action (Step 7, Level III), and also, but to a lesser extent, when initially formulating the optimal course of action (Step 8, Level III), but it would make no sense whatsoever to adopt one as a single final decision (Level V) after passing the filter of consistency tests, one of which should be test of feasibility.

The deliberative committee should be aware of the impossibility of implementing an optimal course of action when the situation being dealt with is a general one, but it might well not be in the case of a specific situation affecting a healthcare professional that has not been brought to its attention. In the first of these cases, it could decide $e x$ officio to continue its deliberations in order to come up with a second-best but a feasible course of action (Step $8_{2}$ or Step $8_{\mathrm{F}}$ ). But in the latter, it should perhaps accept the optimal proposal and, when its unfeasibility is demonstrated, the healthcare professional can bring the case before the committee again, explaining why the initial decision cannot be implemented, these reasons then being taken into account at the level of facts (Level 1) of the new deliberative procedure.

Proposing ethical or normative ideals and deliberating on issues of justice. The explicit inclusion of the test of feasibility emphasizes ethical analysis and the potential identification about the optimal course of action as a normative ideal, whether it matches reality or not, and also keeps the committee's educational function without losing its practical orientation. Limiting itself to identifying optimal courses of action, regardless of their feasibility would refute its practical purpose; restricting 
the scope of its ethical deliberations to fit the real circumstances of the case would condition the purity of its ethical analysis, modify the method's structure and steps and suppress the ethical requirement to seek an optimal course of action, since it would be limited to reproducing reality, thereby eliminating the possibility of imagining better models. The distinction between the ideal dimension and the real one explains why it may be impossible to implement the optimal course of action here and/or now, without depriving it of its relevance as a normative horizon. It serves to identify possible defects in a system or to propose changes to legislation or healthcare policy. The opposite, however, does not hold true: if real conditions of the query are known from the outset, the committee has no obligation to add a reflection on the ideal solution.

Test of feasibility requires equity and fair distribution of resources to be taken into account. This should be seen as an advantage, because the method only allows one problem to be dealt with at a time and questions of justice may have been left to one side; now they can be taken into consideration. The course of action chosen would be the one that is the fairest, most equitable or most efficient: this may even come into contradiction with that chosen as the optimal course of action (Step 8, Level III), if the latter is based on other values or principles, such as autonomy or beneficence, instead of taking justice as a point of reference (Step 4, Level II).

\section{Final decision}

A recommendation, not a command. The decision that constitutes the end point of the deliberative procedure is a recommendation, a proposal based on the best decision and the best possible course of action. It is thus neither a command nor an order that is binding for the healthcare professional. Nor should it be interpreted as an exclusionary reason for following the course of action that has been chosen, but as a valid prima facie reason for considering that such a course of action is the best possible one, and as such, should be implemented.

Seeing the decision as advice or a recommendation is in harmony with a distinctive feature of healthcare ethics committees, consultative bodies that raise a claim to authority (of a moral kind: auctoritas) as the reason for their decisions being accepted and implemented, but which have no power (potestas) to impose them. The committee has the duty to communicate the outcome of its deliberations and the course of action it proposes (Level V) in order to advise healthcare professionals in making of a decision, but 
not to assume their responsibility, since they are who have the final say as to the solution of their problem. ${ }^{67}$ Committee provides the best ethical answer to the query, but cannot replace or take away a healthcare professional's decision-making responsibility.

Unanimity, consensus and dissenting opinion. Prudent and wise deliberation is concerned with issues that may differ with what is contingent. Committee's arguments may be convincing and reasonable, but never apodictic or absolute: another reason, argument, course of action and decision is always possible. Deliberation is not tantamount to consensus, but rather to a prudent and wise decision. ${ }^{68}$ Far from requiring a decision to be unanimous, its essence is that a reasonable and prudent decision should be reached after an exchange of reasons and arguments has taken place.

The possibility of more than one decision at Level $\mathrm{V}$ may be the consequence, first of all, of a matter of content. When an ethically optimal course of action (Step 8, Level III) fails to pass the tests of consistency (Step 9, Level IV), it is necessary to formulate a new and sub-optimal course of action (Step $8_{2}$ ) that can pass the tests and be adopted as the final decision (Level V). As has already been pointed out, deliberative nature of the method requires communication not only of the final decision that has passed all the tests of consistency (Step $8_{2}$, Level III, and Level V) but also of the ethically optimal decision (Step $8_{1}$, Level III) that has failed to do so, meaning that there will be two decisions at Level $\mathrm{V}$.

The existence of more than one decision at Level V may also come about for a subjective reason. When a committee's members hold differing opinions, it will be impossible to arrange an unanimous final decision. In such circumstances, the final decision (Level V) must be adopted by a majority vote, with one or more different courses of action being considered optimal by a minority or even a single member. These must be communicated, in the form of dissenting opinions, to the healthcare professional that made the query, so as to fully and truthfully reflect on deliberative procedure.

Both situations can be seen as positive: unanimity reinforces the authority and persuasive power of decision, whilst its absence can be taken as an example of the fertility of genuine deliberation, of the dialectical wealth existing within the committee and of the latter's plural nature and maturity (if it were to be considered as a symptom of dogmatism or intransigence we would have to talk of a pseudo-deliberative procedure or a failed deliberation).

67. See D. Gracia, J. J. Rodríguez Sendín (dir.), Guías de ética en la práctica médica 2. Ética en cuidados paliativos; D. Gracia, y J. J. Rodríguez Sendín (dir.), Guías de ética en la práctica médica 6. Retos éticos en Atención Primaria, p. 2. 68. See D. Gracia, "Deliberation and Consensus", p. 93. 
A plurality of decisions of this kind is a true reflection of deliberative procedure and enriches the answer to the query, adding an educational dimension to the committee's intervention. The healthcare professional, who has taken the decision, will have more than one option at their disposal, even though the committee's answer establishes an order of priority by proposing one of the decisions as the final one, either because it satisfies the greatest majority or because it is the only one that pass all the tests of consistency, putting forward the others as less optimal alternatives.

\section{A revised deliberative procedure}

The deliberative method has been enhanced through each of its successive versions. Respective its structure and formulations I put forward a further revision, which aims to be a fuller, more coherent and more accurate version of the current bioethical deliberative procedure:

I. Presentation of facts.

Presentation of the case.

II. Deliberation on facts.

Deliberation of the case facts.

III. Deliberation on values.

Identification of moral issues presented by the case.

Choice of the moral problem to be discussed.

Determination of the values in conflict.

IV. Deliberation of duties.

Identification of extreme courses of action.

Search for intermediate courses of action.

Choice of the optimal course of action.

V. Deliberation on the consistency of the decision.

Tests of consistency.

Test of legality.

Test of publicity.

Test of time.

Test of universalizability.

Test of feasibility. 
VI. Making the final decision.

Final decision.

This reformulation of the deliberative procedure combines levels and steps. It begins by restructuring the factual level, differentiating between the new first stage and level (Level I) of the presentation of the case (Step 1), which is descriptive in nature, from a deliberative stage itself (Step 2), now considered to be a level in its own right (Level II). Although both steps belong to the factual stage, only the second one requires deliberation. Dividing this stage into two levels lends the method's structure greater clarity, since it now starts and concludes with two non-deliberative levels (Levels I and VI), reserving deliberative procedure for the intermediate levels (Levels II, III, IV and V).

Tests of consistency level (Level V, previously Level IV) change its name to include a reference to deliberation, because these tests involve a true deliberative procedure rather than being a purely formal check. The five tests of consistency are seen as sections of a single step, namely the transition from (or transformation of) what is ethically optimal to the final decision.

The last level, making the final decision (Level VI, previously Level V), incorporates a stand-alone step (Step 10. Final decision), allowing the deliberative procedure to conclude with a new numbered step. Level VI, like the new Level I, is not a deliberative one. The final or definitive decision is more of a corollary to the procedure, which leads to the said decision as conclusion of a practical syllogism that does not involve any deliberation within the procedure. The revised procedure thus places the deliberation on the facts, values and duties between these two non-deliberative levels. 